\title{
THE PREMATURE RETINA: A MODEL FOR THE IN VIVO STUDY OF MOLECULAR GENETICS?
}

\author{
JOHN T. FLYNN \\ Miami, Florida
}

\begin{abstract}
SUMMARY
Retinopathy of prematurity is a disease of developing blood vessels. Although it is seen predominantly in premature infants requiring life support systems to survive, it does occur in full-term infants, infants with hypoxia, cyanotic heart disease and in stillborn infants. Although oxygen has been considered to be the prime aetiologic agent, evidence for this, particularly in recent years, is not compelling. The timing of the occurrence of the disease is closely related to the conceptional age of the infant rather than weeks post birth, birth weight, gestational age at birth. In addition, the case to case similarity of the disease, as well as the diverse cell types produced in unfavourable outcomes (cicatricial ROP), point to the possibility of an in utero insult to the clone of cells giving rise to the vascular endothelium providing blood supply to the neural retina.
\end{abstract}

"A scientist is supposed to have a complete and thorough knowledge of some subject . . . and is expected never to write on any topics of which he is not a complete master. . . . but it has become next to impossible for a single mind to fully command more than a small portion of the sum total ... I can see no escape from this dilemma than that some venture to embark on a synthesis of fact, and theories at the risk of making fools of ourselves."

E. Schrödinger, $1944^{1}$

\section{INTRODUCTION}

In order to discuss the premature retina, I feel obliged to break the mould and attempt to do as Erwin Schrödinger did in his little book, "What is Life?". 'This monograph provided an enormous stimulus for the field of molecular biology, in spite of the fact that almost every idea in it was wrong. Schrödinger might have been wrong on details, but he was right in asking the fundamental questions and in challenging the right minds of his era to think anew about

From: Department of Ophthalmology, Bascom Palmer Eye Institute, University of Miami School of Medicine, Miami, FL, USA.

Correspondence to: John T. Flynn, M.D., Bascom Palmer Eye Institute, P.O. Box 016880, Miami, FL, USA. the problems of modern quantitative biology. In some small way, I would like to emulate him with regard to the premature retina and, particularly, its vascular development.

\section{NORMAL VASCULOGENSIS}

Let us assume that Professor Ashton was right several decades ago when he formulated his theory of retinal vasculogenesis. ${ }^{2-4}$ We develop retinal blood vessels by a simple and logical program:

Mesenchyme $\rightarrow$ Capillary Meshwork $\rightarrow$ Mature Arteries and Veins

Although some details may be incorrect (mesenchyme may not be precursor but may be glia or some sustentative tissue $^{5-6}$ ), but the big picture is right. It is a finite process, begun at 16 weeks of gestational age in the warm, stable, hypoxic environment of amniotic fluid. It is destined, under normal circumstances, to be carried out in that environment. On a more basic level, the blood supply of the retina is the blood supply of an outpouching of the ventral diencephalon. ${ }^{7.8}$ The diencephalon along with the telencephalon arises from the first neuromere. Because of its origin, it must, in the final analysis, be under the control of a group of master or "smart genes"-12 which specify the cell division, differentiation and migration to distant sites necessary to give rise to the variegated structure of the central nervous system-the neural retina, the cerebral hemispheres, the lateral and medial geniculate and midline thalamic nucli.

The point is: When premature birth occurs, we are privileged to observe a major histogenetic event-the development of the retinal blood vessels, which is usually hidden from our gaze (Fig. 1). What is more, we can study it in vivo as it plays itself out from vessels observable only in the posterior pole to vessels all the way across the retina to the ora serrata. We can witness, for example, how this system solves a very real problem of solid geometryhow adequately to cover the surface of a sphere with a meshwork of soft distensible tubes of varying diameters. In so doing, it adopts clearly different strategies in differ- 


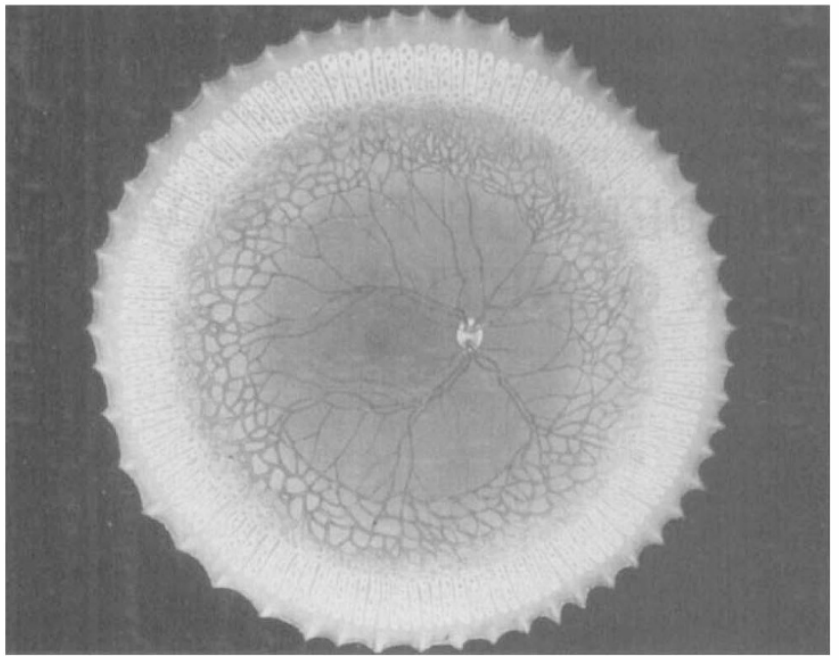

Fig. 1. Artist conception of vasculogenesis with mesenchyme approaching the ora serrata, a chickenwire meshwork of capillaries immediately posterior to it, giving rise to mature arteries and veins (with surviving capillary network between).

ent locations. Compare, for example, the region of the major vascular arcades posteriorly versus the ora serrata anteriorly. Normal vasculogenesis is, in sum, a complex series of genetic and epigenetic events, which leads to the development of the final morphology of the retinal blood vessels at about term. ${ }^{13}$

\section{ABNORMAL VASCULOGENESIS}

Retinopathy of prematurity (ROP) is, to a first approximation, a disease of developing retinal blood vessels. Let us review what we might mean when we say this. First, there is an early stage of the disease which we never see but which, it is plausible to think, must occur. An injury, or series of injuries, wreak havoc to a smooth, coordinated, genetically-controlled developmental program which requires an extremely stable environment and changes it irreparably. The earliest intimation that something is wrong is a detectable change: An abrupt visible border or division between vascular and avascular tissue appears, located somewhere in time and space of the program (Fig.

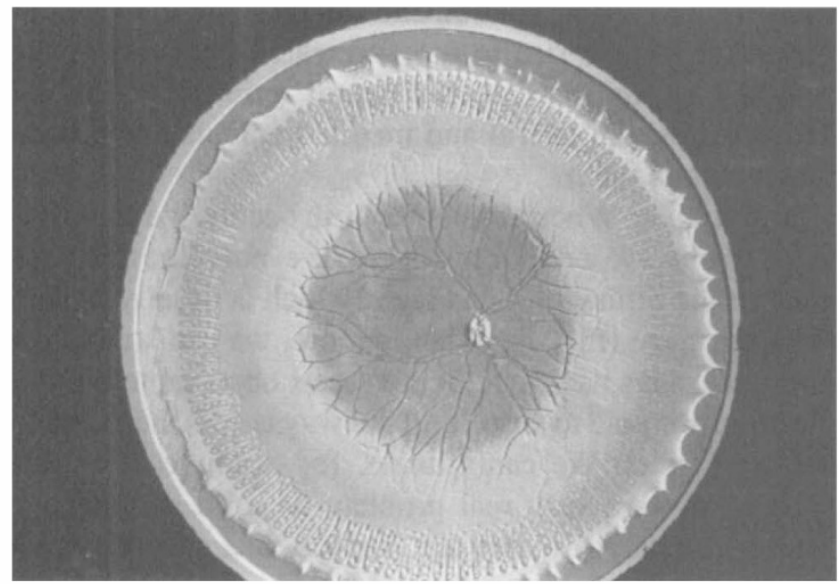

Fig. 2. Artist conception of the injury which results in retinopathy of prematurity. Capillary bed is wiped out and mesenchyme and mature arteries and veins survive in the eye.
2). One reads both dimensions at each retinal locus. We might venture to write a program for how this might come about (Table I). The earliest characteristic the clinician notes is that everything has come to a dead stop in the retina. Observable vessels seem to end in a very fine, sinuous structure which is called a demarcation line. ${ }^{14}$ Map the structure with fluorescein and it fills with the dye $\mathrm{e}^{15.16}$ and no capillary meshwork extends beyond it. It is best understood as a shunt formed to replace the destroyed (or not formed?) capillary bed.

The second step, and it is crucial to separate it for purposes of understanding, is the injury-response program (Table II). Clinically, this is observed as the thickening of the linear demarcation line into a three-dimensional structure, a ridge (Fig 3 ). What is bringing about this thickening? Is it purely hemodynamic? I doubt it on several grounds. First, the evidence of simultaneous new growth of tissue in the form of neovascular membranes at the time of the thickening is overwhelming. Both at the site of the shunt and behind it in already vascularised retina; and above it on the vitreal surface, if one looks carefully. Though the chemical content of the blood, particularly its oxygen, carbon dioxide, bicarbonate and $\mathrm{pH}$ concentration, as well as its haemodynamics, pressure and velocity, are critical triggers to the growth of the dimensions of the structure, its real driving force is the resumption of angiogenesis. But angiogenesis with a difference, which is critical to the outcome for the eye. After a time delay, angiogenesis begins in place with divide as its first command. But instead of a straightforward angioblast to endothelium pathway, two paths are now open: Endothelium and/or other cell type-fibrocyte, glia, collagen precursor cell, etc.

Migrate is its second command. But, once again, two paths are open and they, too, play a critical role in the outcome: Within and outside the internal limiting membrane of the retina. The balance between these two lead to the two general categories of outcome: Regression, ${ }^{17.18}$ where endothelial production and migration within the internal limiting membrane predominate or cicatrization ${ }^{17-20}$ (detachment), where metaplastic cell production and migration outside the internal limiting membrane predominate and result in traction and retinal detachment.

\section{WHY GENETIC?}

Nothing up to this point is outside the mainstream of thought about ROP. However, following in Schrödinger's footsteps, I would now part company with mainstream thought about the disease. My thesis is that retinopathy of prematurity is a disease which is inexplicable without invoking an injury to the genetic program guiding vascularisation and that injury occurs most likely in utero. This is in stark contrast to the dogma of almost a half century that has held ROP to be a prime example of an iatrogenic disease.

Table I

STOP:

Cell division/migration stops

PICK UP THE PIECES: Shunt forms to replace lost capillary bed 
Table II

\begin{tabular}{ll}
\hline START: & $\begin{array}{l}\text { Resume angiogenesis program } \\
(35-40 \text { weeks })\end{array}$ \\
DIVIDE: ANGIOBLAST: & $\rightarrow$ Endothelium \\
& $\rightarrow$ Metaplastic cells \\
MIGRATE: & $\rightarrow$ Within ILM: Regression \\
& $\rightarrow$ Outside ILM: Traction detachment \\
\hline
\end{tabular}

Let us examine the evidence for this astounding assertion. First, evidence on the positive side, with which we are familiar. This is the finding of disease, pathologically indistinguishable from ROP in anencephalics and other fetuses with severe central nervous system anomalies, ${ }^{21-23}$ as well as in full-term infants. ${ }^{24,25}$ It also occurs in its mildest form (the presence of a demarcation line) in stillborn infants. ${ }^{26}$ None of these infants have been exposed to any of the environmental factors thought to play a crucial role in the development of ROP. On the negative side is the intrinsic weakness of the oxygen hypothesis itself as reviewed by Lucey ${ }^{27}$ and, moreover, its failure to explain the development of the disease in hypoxemic infants ${ }^{28,29}$ and in infants with cyanotic heart disease..$^{30}$

On this point, a recent study ${ }^{31}$ delineated a quantitative and independent role for transcutaneous $\mathrm{PaO}_{2}$ values in excess of $80 \mathrm{mmHg}$ in both the incidence and severity of ROP. It is a role which is a minor one, much less strongly predictive of the outcome incidence and severity than either the birth weight of the infant (a marker for retinal vascular immaturity) or the five-minute Apgar score $\leqslant 7$ (a marker for respiratory insufficiency at birth).

The recent findings of Fielder's study ${ }^{32}$ of the onset of the disease as well as data from the CRYO-ROP study ${ }^{33}$ are evidence of another sort. Both are in substantial agreement: the disease arises at a very specific time related to post-conceptional age rather than age post-birth. Across birth weight, gestational age, gender and racial categories, the disease occurs in the retina at a very specific time between about 32 and 34 weeks post-conception (Fig. $4 \mathrm{~A}$ and $B$ ). If one plots this in terms of frequency distributions when the disease occurs by birth weight groupings, it brings the peaks of the distribution very nicely together at the same point in time along the post-conceptional age

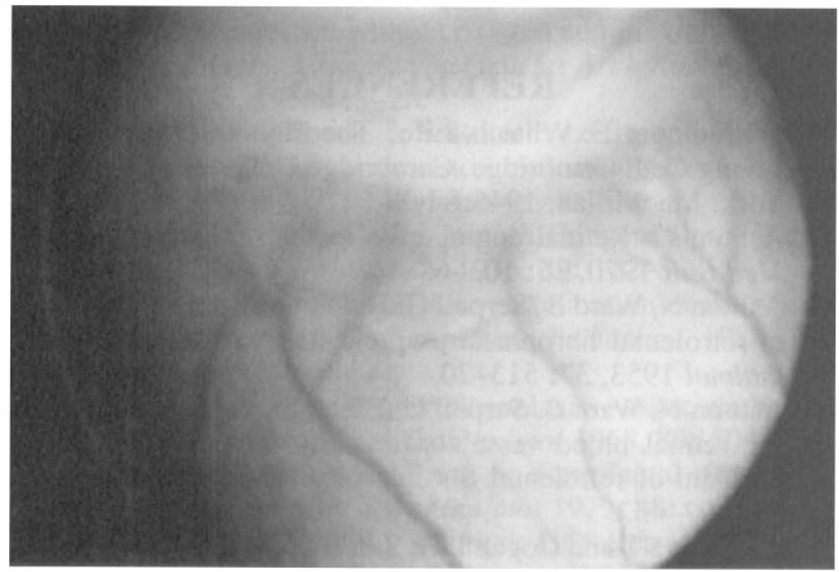

Fig. 3. Early Stage 3 retinopathy of prematurity in the retina of an infant 36-weeks postconceptional age. axis. The point is that such events, tightly time-locked to a clock that started ticking at conception rather than at birth points in the direction of an in utero event when all infants shared a common physical environment rather than an extrauterine environmental event.

That is not to say that environmental factors do not play a role. The evidence to the contrary is enormous. But it has always been troubling to "explain" the inverse relationship between prematurity and the incidence and severity of the ROP by saying simply that it was "immaturity" that accounted for it. What, after all, is immaturity in this context? If, on the contrary, one looks at extrauterine environmental factors as a cumulative type of insult which modifies the severity rather than the occurrence of the disease then this begins to make sense. Infants of very low birth weight and gestational age have an exposure to prolonged hostile extrauterine life during which the severity of their disease will be modified by environmental factors. The heavier, older infant will have a less prolonged exposure to hostile environment and, therefore, less severe disease. Within the framework of the hypothesis, the inverse relationship between birth weight and frequency and severity of the disease makes sense when considered from the aspect of an in utero and extrauterine insult. The in utero event brings about a change in the genetic programme controlling vasculogenesis. This change makes itself manifest at a very specific time post-conception as the earliest sign of the disease. The second event is the cumulative environmental influence on the disease which shapes its final morphology.

This places in another light the whole systematic characterisation of the location, extent and severity of the disease, the fundamentals of the International Classification of Retinopathy of Prematurity (ICROP).${ }^{14}$ Under this viewpoint, the least severe disease, which never gets any worse than Stage 1 (ICROP) and is most frequently, but not exclusively, located in the periphery, would be seen as the "proto-disease", a marker of the in utero insult. It would encompass only those changes in the vasculogenesis component devoid of environmental influences. The more severe disease, both by location and development in severity over time, would then be seen as a more severe combination of both insults. This conception leads to several useful ways of looking at ROP and its environmental influences. By profiling the extra-uterine environment of the disease which remains Stage 1 throughout its course across different birth weights, gestational ages, and at different locations in the retina, one could begin to identify the environmental influences which, by their very presence or absence, result in the lack of progression of the "proto-disease." On the contrary, disease which is very severe in its manifestations would enable us to profile the environmental influences which produce this outcome. The former should have a very different environmental profile of extrauterine life than the latter, which progresses from Stage 1 through Stage 5. Formerly, we would painstakingly compare populations of infants with and without ROP and look for differences in their extrauterine 


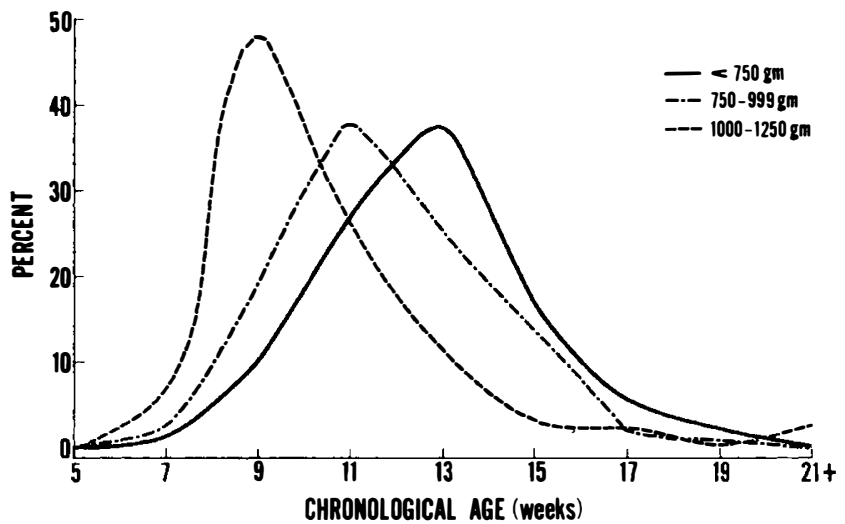

Fig. 4a. Onset of threshold by chronological age and by birth weight. (Reproduced with permission.)

environment as a way of characterising factors independently associated with ROP. Anyone who has been through this brute force exercise knows that it is singularly unrewarding. It is asking the wrong question of the wrong populations. Infants without an in utero insult to their vascular programme cannot develop the disease and can withstand enormous environmental stresses of the type which would lead, in the ROP cohort, to severe disease. This makes the whole point of the exercise futile. The comparison to examine is between infants with mild ROP (Stages 1 and 2), which remains such throughout its course, and the infants with Stage 1-5 disease and look for environmental differences between these.

While the argument above makes the case for an event, time-locked to in utero environment, it does not necessarily imply a genetic basis for the phenomenon. These are, however, several clues available that suggest a genetic type of insult. The first is the stereotypical nature of the disease. Clinicians are so familiar with this that they often overlook it, but the resemblance between retinas with ROP of similar zone, extent and stage is one of its most familiar characteristics. Every retina with the disease (of a given level of severity) looks like every other retina with the same level. It is this very congruity that permitted the development of ICROP. Beyond that feature is still another-the diversity of the cell lines which participate in its outcome. In place of a simple vascular program which produces, in the normal, two, or at most three, cell types to build the vascular bed, retinopathy produces a whole range of diverse cell lines once the angiogenesis program begins again after the its initial sessile stage. These different cell lines are very appropriate for wound healing ${ }^{34,35}$ (a cicatrix), but highly inappropriate for the process of providing a functional vascular network for a segment of the diencephalon. These different cell lines, many of which remain to be identified, would seem best explained as a result of a change in a master genetic programme.

What does the future hold? Research, which in the past has been focused on angiogenesis factors, ${ }^{36,37}$ retinal enzymes, oxygen scavenegers ${ }^{38-45}$ and the like has, it appears, failed to provide a plausible and convincing explanation of why the disease occurs and how it occurs. The way then seems open to look at ROP in the eye of the

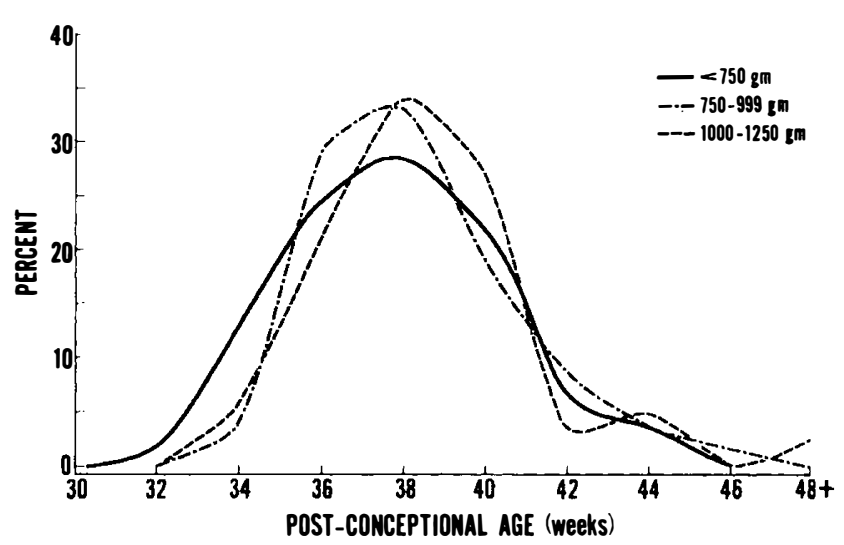

Fig 4b. Onset of threshold by post-conceptual age and by birth weight. (Reproduced with permission.)

premature as an in vivo laboratory for the study of molecular genetics and gene products. The search might begin with the armamentarium of the modern molecular geneticist to identify transcription factors, particularly RNA transcription factors, ${ }^{9}$ products of master or homeobox genes, ${ }^{46,47}$ controlling whole segments of the body and their development. Particularly those homeobox genes concerned with the formation of the first neuromere and its constituent parts. I would suggest that we broaden our search beyond the retinal vasculature alone and look, for example, at the blood supply of the whole of the telencephalon and diencephalon for abnormalities in development. The association of intracranial bleeding ${ }^{48,49,50}$ and its complications and resulting scarring with ROP may not be, by any means, a fortuitous event.

Retinopathy of prematurity has provided to a simple clinician, a fascinating challenge best echoed by Gerald Edelman's words on the future of modern molecular biology, "The central questions of modern molecular biology are ... 'How does the one-dimensional genetic code specify a three-dimensional cell, organism?' and 'How is the proposed answer reconciled with the relatively rapid changes in form occurring in relatively short (evolutionary) times?" 51

Key words: Retinopathy of prematurity (ROP), Normal vasculogenesis, Abnormal vasculogenesis, In utero insult, Genetic basis for retinopathy of prematurity.

\section{REFERENCES}

1. Schrödinger E: What Is Life? The Physical Aspect of the Living Cell. Cambridge, Cambridge University Press. New York: MacMillan, 1945:i-iv.

2. Ashton N: Retinal angiogensis in the human embryo. $\mathrm{Br}$ Med Bull 1970, 26: 103-6.

3. Ashton N, Ward B, Serpell G: Role of oxygen in the genesis of retrolental fibroplasia. A preliminary report. $\mathrm{Br} \mathrm{J} \mathrm{Oph-}$ thalmol 1953, 37: 513-20.

4. Ashton N, Ward B, Serpell G: Effect of oxygen on developing retinal blood vessels with particular reference to the problem of retrolental fibroplasia. Br J Ophthalmol 1954, 38: $397-432$.

5. Kuwabara T and Cogan DG: Studies of retinal vascular patterns. Part I. Normal architecture. Arch Ophthalmol 1960, 64: 904-11.

6. Cogan DG and Kuwabara T: Accessory cells in vessels of 
the paranatal human retina. Arch Ophthalmol 1986, 104: 747-52.

7. Sidman RL and Rakic P: Development of the Human Nervous System. In: Haymaker W, Adams RD (Eds). Histology and Histopathology of the Nervous System. Springfield, IL: C. C. Thomas 1982:3-145.

8. Rakic P: Prenatal development in the visual system in Rhesus monkey. Phil Trans Royal Soc London (Biol) 1977, 278: 245-60.

9. Beardsley T: Trends in biology: Smart genes. Sci Am 1991, 265(2): 86-95.

10. Melton DA: Pattern formation during animal development. Science 1991, 252: 234-41.

11. Ptashne M, Gann AF: Activators and targets. Nature 1990, 346(6282): 329-31.

12. De Robertis EM, Oliver G, Wright CVE: Homeobox genes and the vertebrate body plan. Sci Am 1990, 263(1): 46-52.

13. Wise GN, Dollery CT, Henkind P: The Retinal Circulation. New York, Harper and Row, 1971: 1-18.

14. Committee for the Classification of Retinopathy of Prematurity: An International Classification of Retinopathy of Prematurity. Arch Ophthalmol 1984, 102: 1130-4.

15. Flynn JT, O'Grady GE, Herrera J et al: Retrolental fibroplasia. I. Clinical observations. Arch Ophthalmol 1977, 95: 217-23.

16. O'Grady GE, Flynn JT, Justice J: Fluorescein Angiography in the Study of Retrolental Fibroplasia. In: Shimizu K (Ed). Fluorescein Angiography. Tokyo: Iguka Shoin Ltd 1974: 155-7.

17. Flynn JT: Acute proliferative retrolental fibroplasia: Evolution of the lesion. Albrecht von Graefes Arch Klin Exp Ophthalmol 1975, 195: 101-11.

18. Kushner BJ, Essner D, Cohen IJ, Flynn JT: Retrolental fibroplasia. II. Pathologic correlation. Arch Ophthalmol 1977, 95: 29-38.

19. Flynn JT, Cassady J, Essner D, Zeskind J, Merritt J, Flynn R, Williams MJ: Fluorescein angiography in retrolental fibroplasia. Experience from 1969-1977. Ophthalmology 1979, 86: $1700-23$.

20. Foos RY: Acute retrolental fibroplasia. Albrecht von Graefes Klin Exp Ophthalmol 1975, 195: 87-100.

21. Foos RY: The Spectrum of Nonvascular Proliferative Extraretinopathies. In: Nicholson DH (Ed). Ocular Pathology Update. New York: Masson, 1980: 107-114.

22. Addison DJ, Font RL, Manschot WA: Proliferative retinopathy in anencephalic babies. Am J Ophthalmol 1971 , 74: $967-76$.

23. Stefani FH and Ehalt H: Non-oxygen induced retinitis proliferans and retinal detachment in full-term infants. $\mathrm{Br} J$ Ophthalmol 1974, 58: 490-513.

24. Brockhurst RJ and Christi, MI: Cicatricial retrolental fibroplasia. Its occurrence without oxygen administration and in full term infants. Albrecht von Graefes Arch Klin Exp Ophthalmol 1975, 195: 113-28.

25. Kushner BJ and Gloeckner E: Retrolental fibroplasia in fullterm infants without exposure to supplemental oxygen. Am J Ophthalmol 1984, 97: 148-53.

26. Karlsberg RC, Green WR, Patz A: Congenital retrolental fibroplasia. Arch Ophthalmol 1973, 89: 122-3.

27. Lucey JF and Dangman B: A re-examination of the role of oxygen in retrolental fibroplasia. Pediatrics 1984, 73: 82-96.

28. Bruckner HL: Retrolental fibroplasia-associated with intrauterine anoxia? Arch Ophthalmol 1968, 80: 504-5.

29. Naiman J, Green WR, Patz A: Retrolental fibroplasia hypoxic newborn. Am J Ophthalmol 1979, 88: 55-8.

30. Kalina RE, Hodson WA, Morgan BC: Retrolental fibroplasia in a cyanotic infant. Pediatrics 1972, 50: 765-8.

31. Flynn JT, Bancalari E, Sim-Snyder E, Goldberg RN, Feuer W: Cassady J, Schiffman J, et al: A Cohort study of trans- cutaneous oxygen tension and the incidence and severity of retinopathy of prematurity. $N$ Engl J Med (In Press).

32. Ng YK, Fielder AR, Shaw DE, Levene MI: Epidemiology of retinopathy of prematurity. Lancet 1988, 2: 1235-8.

33. Palmer EA, Flynn JT, Hardy RJ, Phelps DL, Phillips CL, Schaffer DB, Tung B: Incidence and early course of retinopathy of prematurity. Ophthalmology 1991, 98: $1628-40$.

34. Foos RY: Pathological Features of the Clinical Stages of Retinopathy of Prematurity: In: Retinopathy of Prematurity: A Clinician's Guide. Flynn JT, Tasman W (Eds). New York: Springer-Verlag, 1992:23-37.

35. Hjelemeland LM and Harvey AK: Growth Factors: Solvable Mediators of Wound Repair and Ocular Fibrosis. In: Retinopathy of Prematurity: Problem and Challenge. Flynn JT, Phelps DL (Eds). New York: A. R. Liss, 1988:87-102.

36. Folkman J: Tumor angiogenesis: Therapeutic implications. N Engl J Med 1971, 285: 1182-6.

37. Folkman J, Weisz PB, Joullié MM, Li WW, Ewing WR: Control of angiogenesis with synthetic Heparin substitutes. Science 1989, 243: 1490-3.

38. Frank L and Groseclose EE: Preparation for birth into an $\mathrm{O}_{2}$-rich environment: The antioxidant enzymes in the developing rabbit lung. Pediatr Res 1984, 18: 240-4.

39. Fridovich I: Superoxide dismutases. Ann Rev Biochem 1975, 44: 147-59.

40. Katz ML, Parker KR, Handelman GJ, Bramel TL, Dratz EA: Effects of antioxidant nutrient deficiency on the retina and retinal pigment epithelium of albino rats: A light and electron microscopic study. Exp Eye Res 1982, 34: 339-69.

41. Robison WG Jr, Kuwabara T, Bieri JG: Vitamin E deficiency and the retina: Photoreceptor and pigment epithelial changes. Invest Ophthalmol Vis Sci 1979, 18: 683-90.

42. Phelps DL and Rosenbaum AL: Vitamin E in kitten oxygeninduced retinopathy. II. Blockage of vitreal neovascularisation. Arch Ophthalmol 1979, 97: 1522-6.

43. Kretzer FL, Mehta RS, Johnson AT, Hunter DG, Brown ES, Hittner HM: Vitamin E protects against retinopathy of prematurity through action on spindle cells. Nature 1984, 309: 793-5.

44. Kretzer FL, McPherson AR, Rudolph AJ, Hittner HM: Pathogenic mechanism of retinopathy of prematurity: A controversial explanation for the efficacy of oral and intramuscular Vitamin E supplementation and cryotherapy. Bull NY Acad Med 1985, 61: 883-900; Erratum 1986, 62: 128.

45. Kretzer FL, McPherson AR, Hittner HM: An interpretation of retinopathy of prematurity in terms of spindle cells: Relationship of Vitamin E prophylaxis and cryotherapy. Graefes Arch Clin Exp Ophthalmol 1986, 224: 205-14.

46. Schindler JM: Basic developmental genetics and early embryonic development: What's all the excitement about? $J$ NIH Res 1990, 2: 49-55.

47. Gould SJ: Of mice and mosquitoes. Natural History (July) 1991, 12-20.

48. Lucey JF: Perinatal Intracranial Hemorrhage and Retinopathy of Prematurity: Currently Nonpreventable Complications of Premature Birth? In: Retinopathy of Prematurity: Problem and Challenge. Flynn JT, Phelps DL, (Eds). New York: A.R. Liss, 1988: 37-40.

49. Hungerford J, Stewart A, Hope P: Ocular sequelae of preterm birth and their relation to ultrasound evidence of cerebral damage. Br J Ophthalmol 1986, 70: 463-8.

50. Brown DR, Milley JR, Ripepi UJ, Biglan AW: Retinopathy of prematurity. Risk factors in a five-year cohort of critically ill premature neonates. Am J Dis Child 1987, 141: 154-60.

51. Edelman G: Topobiology: An Introduction to Molecular Embryology. New.York. Basic Books, 1988: 4. 